European journal of American studies

\title{
Cormac McCarthy and the Genre Turn in Contemporary Literary Fiction
}

James Dorson

\section{OpenEdition}

\section{Journals}

Electronic version

URL: https://journals.openedition.org/ejas/12291

DOI: $10.4000 /$ ejas. 12291

ISSN: 1991-9336

Publisher

European Association for American Studies

Electronic reference

James Dorson, "Cormac McCarthy and the Genre Turn in Contemporary Literary Fiction", European journal of American studies [Online], 12-3 | 2017, Online since 04 December 2017, connection on 08 July 2021. URL: http://journals.openedition.org/ejas/12291 ; DOI: https://doi.org/10.4000/ejas.12291

This text was automatically generated on 8 July 2021.

Creative Commons License 


\title{
Cormac McCarthy and the Genre Turn in Contemporary Literary Fiction
}

\author{
James Dorson
}

1 As a writer of four Westerns, a crime thriller, and a postapocalyptic science-fiction novel, to say that Cormac McCarthy writes genre fiction is to state the obvious. At the same time, McCarthy's prose style is among the most idiosyncratic in contemporary literature, to the extent that it is widely copied and parodied. These two observationsthat McCarthy's work is generic and unique-have posed a challenge to critics, one that they have mostly dodged by emphasizing the distinctiveness of his style over the genericity of his plots and characters. Georg Guillemin, for instance, identifies a stark opposition in McCarthy's work between genre and "complexity"-his synonym for literariness. Explaining why McCarthy's first bestseller, All the Pretty Horses (1992), was so popular with a mainstream audience, Guillemin writes that "[t]he simplicity of the quest stories, the generic proximity to the Western, and the conventionality of the plot structures as heroic journeys have apparently caused the novels' complexity to go largely unacknowledged" (102; my italics). He concludes that "the secret of the novel's success" is that "many readers have taken All the Pretty Horses for little more than an unconventional Western" (109). Separating conventionality from complexity, Guillemin effectively splits McCarthy in two: a popular, lowbrow McCarthy and a serious, highbrow McCarthy. This reading doesn't only imply a clear hierarchical relationship between two distinct McCarthys, it also implies that there is a real McCarthy, which only discerning critics can see, and a fake McCarthy, who lures in gullible readers unable to tell when the generic pleasures of the text are being undermined by its complexity.

2 This distillation of McCarthy's unique literariness from his generic conventionality became a critical necessity as McCarthy's readership grew in the 1990s. If the premise of the highbrow/lowbrow distinction in McCarthy criticism could remain tacit while he was still a writer's writer living in relative obscurity, where the general unpopularity of 
his work could be taken as a token of his literary credentials, once the culture industry embraced him, his position outside of that industry had to be defended. Thus, ever since his popular breakthrough with All the Pretty Horses, critics have taken his popularity as a challenge to reveal how his work transgresses, subverts, or transcends what makes it so agreeable to most readers. The real McCarthy is the one Steven Frye claims as "a 'philosophical' novelist in the most profound sense" (4)-surely not the one heralded by the Wall Street Journal as "Hollywood's Favorite Cowboy," or the one on television leisurely chatting with Oprah Winfrey.

Whichever version of McCarthy one prefers, it is becoming increasingly difficult to maintain the distinction between a highbrow and a lowbrow McCarthy. The ingrained modernist premises of the high/low binary, which survived even the postmodernist embrace of popular culture, are now more than ever in need of revision as literary fiction has taken an unmistakable genre turn. Sacrificing the popular McCarthy on the altar of literary purity is a critical move that has become all but obsolete as literary writers today are adopting once shunned genres-horror, science fiction, and fantasy, in particular-in new and unprecedented ways. Joshua Rothman observes that with the recent foray of literary writers into genre fiction, "it's no longer taken for granted that important novels must be, in some sense, above, beyond, or 'meta' about their genre." But while it is clear that the literary field is currently in a state of disarray and reorganization, where old hierarchies are crumbling and new ones are being formed, the actual significance of the genre turn is far from clear.

In a recent volume on The Poetics of Genre in the Contemporary Novel (2016), Tim Lanzendörfer writes that 'the consequences of what is possibly a 'turn' to genre in the contemporary novel have remained under-theorized, both with regards to understanding how and what genre is and does, and to the extent of the turn to genre" (3). The reading in the volume by Yonatan Englender and Elana Gomel of McCarthy's The Road (2006) as science fiction is a welcome attempt to understand the genre work in McCarthy's most popular novel, albeit one that reverses the dominant critical tendency by focusing exclusively on its generic aspects. The most interesting thing about McCarthy's genre fiction, however, and by extension the broader cultural turn to genre that his work represents (and is arguably a major influence on), is the combination of literariness and genericity-what, for the sake of convenience, I will refer to here as literary genre fiction. ${ }^{1}$ In a short essay that reads McCarthy's work from the perspective of crime fiction, David Schmid writes that "[w]e need a more nuanced understanding of the relation between literary and genre fiction, one that avoids maintaining each half of this binary in isolation, and instead imagines the possibility of hybrid mixture." Taking up Schmid's cue, this essay asks how we might understand McCarthy's genre fiction without either reading it as "above, beyond, or 'meta" about its genres nor singling out its genre effects for analysis. In seeking a possible answer to this question, I will first examine McCarthy's genre turn vis-à-vis what Mark McGurl in his influential study of the importance of creative writing programs for postwar US fiction calls The Program Era (2009). This step will lead me to address what I believe are two of the major stakes in the genre turn today: a new understanding of reality in contemporary literary genre fiction, as well as a new relationship between literature and institutions. 


\section{Cormac McCarthy and Genre Fiction in the Program Era} the modernist, counterpastoral grain of William Faulkner and Flannery O'Connor. ${ }^{2}$ His early novels frequently employed gothic tropes that others before him had used to challenge the pastoral mythology of the US South. These novels did go beyond the genres they used in order to challenge the myths informing them. The same may be said of Blood Meridian, which is usually read as a revisionist Western. But the labeling of Blood Meridian as revisionist is also a way of sidestepping that it is, in fact, a Western. Unlike his Southern Gothic work, Blood Meridian can be read as a genre piece in its use of fixed character types and emphasis on action over interiority. While his 1979 novel Suttree is a Joycean exploration of personal autonomy-with the protagonist in the end setting forth, Stephen Dedalus-like, to shape his own destiny-no such thing as personal autonomy exists in Blood Meridian. This is not only due to the extensive reach of novel's evil antagonist Judge Holden, but a result of the genre conventions that forego the psychodramas of interiority which define much literary fiction. The Border Trilogy is even more generic in its "flat" characterization of John Grady Cole, "the allamerican cowboy" (Cities of the Plain 3), and its more classical Western plots. Being far less revisionist than Blood Meridian, All the Pretty Horses (1992) may well be considered a forerunner to the recent genre turn-and not only an attempt "to deconstruct as a destructive lie" the cultural myths that inform it (Cant 7). ${ }^{3}$

But why does McCarthy turn to the Western if not to deconstruct it? We are so accustomed to reading fiction as either against mainstream culture (Myth-and-Symbol style) or complicit with it (New Americanist style) that it is difficult to think of what else literature might do. To assess the work of genre in McCarthy's fiction, it is helpful to take a step back from the resistance-versus-complicity debate to examine the larger institutional context of literary production and criticism. McGurl's account of how creative writing programs shaped postwar fiction in The Program Era offers one such model to position McCarthy in respect to the literary field. In mapping the institutional conditions of late modern and postmodern fiction, McGurl shows how the critical poles of resistance and complicity are dialectically reversible. While creative writing programs in the postwar years institutionalized a modernist aesthetic averse to genre fiction, which was understood as limiting human expression to preformed molds, this aversion was reversed once high culture itself was perceived as oppressive by the 1960s. At that time, McGurl writes,

valuing genre fiction meant reversing the ideological valance given mass culture by T. W. Adorno, Dwight Macdonald, Mary McCarthy, and other intellectuals of the 1950s: no longer the domain of a regressive, proto-fascist mass mind, popular culture would now be understood as a force of liberation from the strait-jacket proprieties of 'official' high culture. Just as important, it entailed a revaluation of the bad conventionality associated with genre fiction, the 'formulaic' quality that can make individual titles seem the literary equivalent of widgets coming off a conveyor belt. Instead, the charge of 'conventionality' would be aimed at the formerly insurgent, but now wholly respectable, modernist literary tradition itself, sitting there fat and happy on the college syllabus. (Program Era 217)

The appropriation of genre fiction during the 1960s and 1970s by postmodern writers such as Ishmael Reed (whom McGurl takes as his example) was for many of the same 
reasons that modernist writers had rejected it earlier in the century. What both developments have in common-the modernist turn against genre and the postmodern turn to genre-was the rejection of "conventionality." McGurl describes the program era as underwritten by a paradoxical "institutionalization of anti-institutionality" (Program Era 221; original italics), which accounts for the incredible capacity of program era fiction to transform itself whenever it becomes too programmatic.

The most recent turn to genre marks something substantially different, however. As Andrew Hoberek writes in his introduction to a 2007 special issue of Twentieth Century Literature on the possible end of postmodernism, "there is a difference between the transitional but still self-consciously 'literary' appropriation of popular genres in the work of authors like Barth and Pynchon... and a newer tendency to confer literary status on popular genres themselves" (237-238). Instead of incorporating conventional genre elements within an experimental narrative framework, Hoberek argues that contemporary literary fiction tends rather toward the wholesale adoption of genres "as a framing device" ("Introduction" 238). In a more recent essay on The Road, Hoberek reads genre in McCarthy's work against the aversion to genre fiction in the program era. Drawing on McGurl's account, Hoberek claims that "[i]f genre fiction constitutes something like the repressed unconscious of program era fiction... then McCarthy is one of a number of writers who have recently undermined this structure by embracing genre models" ("Aesthetics of Exhaustion" 485).

9 Convincing as Hoberek's argument is that the recent genre turn challenges the aesthetic ideology of creative writing programs, McGurl's own account poses several problems for exempting McCarthy from the program. The first obstacle to considering McCarthy beyond the pale of the program era is that McGurl counts him as part of it. Describing McCarthy as "the most 'out on the range" writer in a group of writers including Don DeLillo and Thomas Pynchon, who all achieved success on account of the market and support from non-academic institutions rather than through the channels of higher education, McGurl notes that McCarthy "got his start by publishing stories in the campus literary magazine at the University of Tennessee," and mentions his affiliation with the "quasi-academic Santa Fe Institute" (Program Era 30, 415fn). One of the strengths of The Program Era is its grand sweep, its attempt "to map the totality of postwar American fiction" (32). The program era doesn't only include writers coming out of or teaching creative writing programs, but the whole gamut of cultural expressions that have been shaped by the institutions of higher education. Referring to "the institutional apriori" of postwar cultural production, McGurl polemically asks, "Is there, after all, a space outside institutions for postwar American writers?" (Program Era 371; original italics). The fact that McCarthy writes "out on the range" fiction and throughout his career has kept the literary intelligentsia at bay doesn't qualify him as outside the program for McGurl.

Yet Hoberek is right that genre fiction functions as the Other in McGurl's account of the program era. This is most clear when genre fiction is considered in relation to the three key principles that form the aesthetic matrix of creative writing programs. McGurl summarizes these principles, each one accompanied by the slogan under which it was popularized, as "experience" ("write what you know"), "craft" ("show don't tell"), and "creativity" ("find your voice") (Program Era 23). Each principle is constituted against a version of genre fiction as formulaic and mass produced. 
11 First, genre as an impersonal set of conventions jars with the personal experience that complements the technical discipline of craft in the program. As McGurl writes:

By contrast to popular genre fiction-telling of outlaws, detectives, vampires, moon men, and other things the writer has probably never seen-autobiographical selfexpressivity would remain an essential element of the late modernist writing program aesthetic, providing a dialectical counter to the professional impersonality of craft. (Program Era 102)

12 Genre can't function as a dialectical counter to self-expressivity, because it is not a technique like craft, but constituted by generic expectations about plot and character types that violate the expression of individual selves. Genre fiction defers what McGurl calls "the autopoietic thematization of authorship" at the heart of the program era (Program Era 51). Even in cases where genre writers partly base their stories on personal experience, as when Dashiell Hammett draws on his years working as a Pinkerton detective or Chester Himes uses material from his prison years for his hardboiled detective fiction set in Harlem, lived experience is subordinated to genre conventions, which reconfigure the personal into the typical.

Regarding craft, the second stylistic principle of the program, the relation to genre fiction is adversarial by definition. If craft and genre are similar in the sense that they both recognize the social labor that goes into cultural production-a skill-set carried on by time-honored traditions of work versus the overt reliance on the work of past genre writers-they differ in respect to the quality of that labor. While genre fiction bears associations of industrial production for a mass market, craft suggests preindustrial, unalienated labor. However, the original arts-and-craft movement was not preindustrial, but emerged in the late nineteenth century as a reaction to industrial mass production. The magazines in which much genre fiction was first published-such as Argosy or Black Mask-prioritized narrative efficiency and often paid writers per word. In contrast, the notion of craft rejects direct instrumentality and machine-like efficiency in favor of painstaking care in the labor process itself. In terms of "the autopoietic thematization of authorship," it is easy to see how McCarthy, who has consistently spurned writing or talking about his own work or occupation as a writer, falls outside the purview of the program. In terms of craft, however, this is not the case. From biographical readings of McCarthy learning stonemasonry to detailed accounts of exquisitely crafted objects in his novels to his beautifully wrought prose style, McCarthy is the consummate writer as craftsman. ${ }^{4}$ Read only in terms of craft, McCarthy fits neatly into the program aesthetic.

Yet McGurl's book is compelling not because of how it breaks down the aesthetic premises of the program era into three key ingredients, but because of how it relates them dialectically. The question, then, is what happens to the technical impersonality of craft when it no longer has the dialectical opposite in autobiographical selfexpressivity? Combining the impersonal technique of craft with the impersonal conventions of genre, as McCarthy does, creates a different stylistic dynamic. Craft in McCarthy is not used to discipline the expression of personal experience, but to hone the expression of conventions; it is not mobilized against the standardization of cultural products, but used to intensify the power of genre. The crafted literary style of McCarthy's genre work serves as a formal correlative to its generic plots. The passage in Blood Meridian usually cited by critics as an example of McCarthy's high style, the Comanche attack that decimates the filibusters early in the novel, heightens the effect of terror in what is a stock Western scene of a surprise attack by Native Americans. The 
function of the highly literary style here is not to undermine the genre convention of the Indian Attack, but to make it more effective, more terrifying. The same could be said of the pathos of loss in the Border Trilogy, a staple of old West eulogies, which is amplified by the lyrical prose; or the stylized minimalism of No Country for old Men (2005), which intensifies the narrative suspense of the crime thriller. The reconciliation of craft and genre in McCarthy's work, then, is very different from what McGurl calls "meta-genre fiction," in which a popular genre "is both instantiated and ironized to the point of becoming dysfunctional in the production of its conventional pleasures" (Program Era 217). The function of craft in McCarthy's genre fiction is to heighten the conventional pleasures (or terrors) of plot, not to obstruct them.

To be sure, this is not to say that McCarthy's work is not reflexive. As David Holloway argues, the Border Trilogy may be read as "a series of statements about storytelling" (27). Yet the mode of reflexivity in the program era and genre fiction is fundamentally different. If stories in program era fiction are fashioned out of the creative transformation of personal experience, in genre fiction, to paraphrase McCarthy, stories are made out of stories. Here we see how the last principle of the program era, creativity, is transformed by the recent genre turn. Rather than a question of individual originality, creativity in literary genre fiction is turned into a question of social practice. While the "autopoietic" reflexivity at the center of program era fiction refers back to the creative writer, reflexivity in genre fiction primarily refers back to its genre conventions. When John Grady Cole is called "the all-american cowboy" or Billy Parham is caught reading Destry, the Border Trilogy self-consciously cites the Western conventions it uses. But even when genre fiction doesn't make its generic debt explicit, its very existence as genre fiction carries with it a reflection on the conventions that structure it. Instead of thematizing authorship, the Border Trilogy thematizes the act of storytelling.

It is significant that we encounter a great many storytellers in McCarthy's work, but never any professional authors. Storytelling in McCarthy refers back to an oral tradition in which the act of storytelling is a social practice, not the solitary business that novel writing is often imagined to be. ${ }^{5}$ The turn to genre, then, is a turn away from storytelling as reflexive self-expression to storytelling as reflexive social allegory. It is in this sense that "genre becomes a means of analyzing the cultural work of literature, and of the cultural context in which it is produced" (Lanzendörfer 5-6). As a social practice, the function of storytelling is to organize and stabilize the world for us. As a reflexive social practice, the function of storytelling is simultaneously to call attention to its role in organizing reality. The notion of creativity implied in this sense of storytelling doesn't refer to how we express ourselves in spite of the restrictions of cultural institutions and norms, but how we understand the world through institutions and the norms informing them. By shifting the cultural function of storytelling away from romantic self-expression to a reflexive social practice, the locus of creativity shifts from individuals to the conventions that make the world livable.

\section{The Reality of Genre Fiction}

17 If we consider this development in the socioeconomic context of the program era that McGurl identifies, namely the creative economy, then the redefinition of craft and creativity precipitated by the genre turn challenges the creative economy's dictum to 
"think outside the box." Writing genre fiction means thinking inside a "box" of established conventions. ${ }^{6}$ The function of creativity here is not to reconfigure personal experience, but to explore the aesthetic and ideological possibilities encoded within a given genre. While these possibilities differ from genre to genre, observers of the recent genre turn have emphasized genre fiction's ability to represent social possibilities that exceed the limits of realistic representation. In Ramón Saldívar's influential essay on postrace aesthetics, for instance, he reads the turn to genre in US ethnic fiction as indicative of how twenty-first-century ethnic writers are "exerting their force against the realist imagination" (581). The "hybrid amalgam of realism, magical realism, metafiction, and genre fictions such as science fiction, graphic narrative, and fantasy proper," which Saldívar calls "speculative realism," is the formal correlative of "ethnic literature's utopian allegiance to social justice" (585). For Saldívar, in short, the postrace novel "marshals fantasy to explore and understand alternatives to the contemporary world" (577).

Hoberek ascribes a similar function to contemporary literary genre fiction, which he reads as a demonstration of "the power of imagination" ("Aesthetics of Exhaustion" 497). Here the turn to genre represents a recuperation of what he calls the "counterfactual imagination of things that realism misses" (496). Such an understanding of genre fiction, however, relies upon a sharp opposition between realism (as the representation of reality) and genre fiction (as the representation of the imaginary), which is a distinction more commonly upheld by literary critics than genre fiction writers themselves. To say that genre fiction frees the imagination from the constraints of realism is to shift the preference from one to the other, as has been done so often before. ${ }^{7}$ But realism doesn't only miss the counter-factual; it often misses the factual as well. Rejecting the dichotomy between realism and genre fiction, Ursula K. Le Guin calls her science fiction a "thought-experiment," which aims "not to predict the future... but to describe reality, the present" ("Introduction" xiv). In her novella The Word for World is Forest (1972), for instance, the relation between dream and reality is reversed: the murderous Captain Davidson devoted to "hard facts" is depicted as out of touch with reality, while the natives of the planet Athshe, described as "dreamers," turn out to have a better grasp on reality. Realism has always defined itself against melodramathe modus operandi of genre fiction-as a misrepresentation of reality. For Le Guin, however, it is the commitment to a positivistic worldview that is dangerously misleading. This alternative conception of reality is partly what is at stake in the recent genre turn. It is not just that literary fiction has turned to genre in order to "explore and understand alternatives to the contemporary world," but that genre is employed to explore and understand contemporary reality itself.

This has become necessary as reality is becoming increasingly indecipherable by means of realistic representation. As Gérard Genette observes, vraisemblance in literature rests not on any direct correspondence with reality, but with "the consensus of vulgar opinion" (243), which is to say, "a body of maxims and presuppositions that constitutes, simultaneously, a vision of the world and a system of values" (240). It is this vision of the world, rooted in the narratives and institutions of modernity, which is in need of revision today. In other words, the "consensus" of reality is undergoing a period of crisis and transformation as modern narratives of the world and our place in it are giving way to new and radically different ways of perception. Among these is a new understanding of human beings (posthumanism), nature (the anthropocene), politics 
(the end of the "liberal consensus"), and economics (neoliberalism). All of these changes have unsettled our vision of reality, shaking up once ingrained beliefs about the world that grew out of and shaped Western modernity. The genre turn may be considered the formal response to this crisis of reality. As the "consensus" of reality changes, so do our representations of it. Understood in this way, the significance of the genre turn is not that literature today prioritizes the imaginative power of genre fiction over verisimilitude, or vice versa. Rather, the imaginative power of genre fiction is becoming the best way to make sense of a world that no longer strictly corresponds to received notions about what constitutes reality. The turn to genre, then, is less a turn away from reality to the imaginary than a turn toward the real through the imagination.

The Road serves as a good illustration. The most "realistic" view of the postapocalyptic world in the novel is that held by the boy's mother. When the father begs her not to kill herself, telling her that she is "talking crazy" in response to her claim that suicide is "the right thing to do," she counters: "No, I'm speaking the truth. Sooner or later they will catch us and they will kill us. They will rape me. They'll rape him. They are going to rape us and kill us and eat us and you wont face it" (48). The sheer nastiness of the world in The Road with its roving armies of cannibals gives readers no reason to doubt that the mother's prediction is the most probable outcome of their struggles. The father cannot help but share her view, even if he doesn't act on it. His wife's words - "You will not face the truth. You will not" (58)-continue to haunt him throughout the novel. But if the father does face the truth that their situation is hopeless-indeed, he does little else in the recurring passages of interior monologue that break up the narrative action-he doesn't share that view with his son. Part of the affective power of the novel is that both the father and readers know that their struggle is futile, and yet they persevere. Rather than telling his son what he believes is "the absolute truth of the world" (100), he tells him that they are the "good guys" and "carrying the fire." The boy may have his doubts about this, but he believes it enough to guide his behavior and vex his father with his compassion toward strangers. The trick that the novel pulls on readers is that the melodramatic story of the world that the boy believes in, but which both the mother and father (as well as readers convinced by the inexorable darkness of the world in The Road) regard as a fiction invented by the father to encourage his sonthat this melodramatic fiction turns out to be true. In the end, when the boy is rescued by a family that seems too good to be true, the boy's view is redeemed as realistic. Instead of being counter-factual, it turns out that he was facing the facts all along, melodramatic as they are, and that the mother's grim realism was an escapist fantasy preventing her from perceiving the improbable reality of the world in The Road: that there are in fact "good guys" out there. The novel essentially stages a passage from a view of reality informed by a now obsolete consensus that "good guys" are unrealistic to a worldview informed by genre fiction, where the existence of good and evil is a reality to be expected-a revised "consensus" of reality that requires a corresponding revision in the mode of realistic representation, which the novel embodies through its genre form.

21 The haunting, postapocalyptic horrors of The Road, but certainly also the hallucinatory scenes of violence in Blood Meridian, suggest that reality itself is fantastic. Whether the Indian wars or drug wars in the Southwestern borderlands or a world on the brink of extinction, these realities defy a commonsensical view of reality to the extent that they are best understood through the melodramatic imagination of genre fiction. In an essay 
on the "Zombie Renaissance" (2010), McGurl refers, like Saldívar, to the recent genre turn as "speculative realism." Instead of an alternative to reality, however, the allegorical work of genre fiction for McGurl registers a different kind of reality. Like melodrama, it provides us with "speculative access to the superhuman designs, whether spiritual or natural, that structure consciousness from without." Such "designs may constitute the ultimate reality," McGurl continues, "in comparison to which ordinary experience is only a kind of dream, but when they are rotated into the space of representation they can look very 'unrealistic' indeed." That realistic description is based on the observation of "ordinary experience" is not to say that experiences of the extraordinary are not real. Genre fiction may be used to describe a reality that escapes the boundaries of ordinary perception, such as the temporal disjunctions, vast spatial scales, and the human decentering that are transforming reality in the twenty-first century.

\section{The Institutional Turn}

This shift in the relationship between reality and genre fiction has implications for how we conceive of the relationship between reality and institutions as well. Just as literary genres shape our encounter with a text, institutions shape our experiences and expectations of the world. Both "provide a network of norms through which our experience is made culturally meaningful" (Fishelov 2). In this sense, the turn to genre in contemporary literary fiction is also an institutional turn. Unlike the institutionalized anti-institutionality of the program era, literary genre fiction has a different relationship with institutions in that it overtly recognizes institutionality as its condition of possibility. Institutions in this view are a vehicle of expression, not what writers need to escape in order to find their "authentic" voice. The institution of genre is regarded as something that both constrains and enables literary expression; or, rather, something which enables expression through the constraints placed on it. As John Frow writes about genre, "its structuring effects are productive of meaning" (10). This contrasts sharply with a modernist view of genre, conceived in Alain RobbeGrillet's words as "a pre-existing mold into which to pour the books of the future" (qtd. in Culler 51). In recent literary genre fiction, as well as in contemporary genre theory, genres are no longer viewed as stable archetypical forms preceding expression, but as reflexive forms actualized in the making. ${ }^{8}$ And in the same way that genres are not "molds" into which literature is poured, institutions are not regarded as imposed on reality, but constitutive of it.

Concomitant with literary genre fiction's different relationship to institutions is a new emphasis on extra-institutional spaces. There is a sustained focus throughout McCarthy's work on what escapes modern institutions. Organizational theorist André Spicer uses the term "extitution" to refer to what exists outside of institutions: "a kind of 'formless life'... that exceeds, disturbs and does not fit with an institution" (26). Characters from McCarthy's early novels such as Arthur Ownby in The Orchard Keeper (1965), Lester Ballard in Child of God (1973), or Gene Harrogate in Suttree (1979) are all examples of personified "extitutions" that exist on the peripheries of institutions. In these novels, institutions are represented as paradigmatically modern, that is, as disciplinary spaces of enclosure. Ownby, Ballard, and Harrogate are relentlessly pursued by institutions such as the prison, the hospital, or the welfare program seeking 
to contain them. While McCarthy never represents the outside of institutions as a space of human emancipation-as Jay Ellis observes, "nowhere in McCarthy is there the celebration of freedom" (29)-there is nevertheless a romantic residue in the picaresque adventures of his characters prior to Blood Meridian trying to escape the clutches of disciplinary institutions. In McCarthy's genre fiction, however, especially Blood Meridian and The Road, the focus shifts from the impossibility of escaping institutions to the sheer horror of what is outside of them. Here the outside of institutions, represented by the sublime deserts in Blood Meridian and the postapocalyptic wasteland of The Road, are not spaces of human fulfillment nor even comical (however dark) adventure, but of death and destruction.

If the program era was characterized by a negative view of institutions as "iron cages" limiting human potentials, much recent fiction is characterized by a negative view of what is outside institutions. This development is no doubt in part a reflection on the decline of modern disciplinary institutions, based on clear categories and sharp boundaries, and the rise of what Gilles Deleuze calls "control society," where institutional barriers are giving way to more flexible control mechanisms. As the long anticipated retreat of disciplinary institutions has not led to more freedom in any utopian sense, but rather to more intrusive forms of rationalization and selfmanagement, the anti-institutionality of the program era is being replaced by a new institutional nostalgia. David Foster Wallace, for instance, who was profoundly influenced by McCarthy, represents disciplinary institutions as a refuge from the mental wilderness of his characters, often existing in a state of anomie, or lawlessness. ${ }^{9}$ However, this also means that all institutions for Wallace are essentially the same: it doesn't matter whether it is Alcoholics Anonymous or a tennis academy in Infinite Jest (1996) or the IRS in The Pale King (2011), they all serve the same therapeutic purpose of calming down his characters by submitting them to a rigid, rule-bound order, which returns them to a state of nomos and clear boundaries. While institutions are generally regarded as obstacles to self-fulfillment in the program era, this is exactly the attraction that impersonal institutions hold for Wallace: they prevent the fulfillment of a self that is ultimately a terrifying void. Yet, as McGurl observes in an essay on Wallace, "an institution against nothing is always also an institution of nothing" ("Institution of Nothing" 46). At the same time as Wallace reverses the relationship to institutions in the program era, he also empties them of content.

More nuanced in terms of its relationship with institutions is Colson Whitehead's 2011 zombie novel Zone One. Branded on its cover as a "zombie novel with brains," the novel tongue-in-cheek announces itself as a blend of literary and genre fiction. It is written in a literary mode often reminiscent of McCarthy's prose, as when it describes zombies as "a succession of imponderable tableaux" (48), "an army of mannequins" (48), or observes "their mindless pantomime" (90)-a choice of words and estranging imagery that triggers clear associations with McCarthy's high style. While the novel, like The Road, also represents the collapse of human institutions and, in this case, the zombie horror that ensues, it refuses the reduction of institutions to a set of rules embraced for their own sake. Through its protagonist's search for shelter, Zone One explores various forms of organization, from the family to the social collective to state bureaucracy, only to dismiss each one in turn. It ends with the protagonist's rejection of the dreary prospect of "replicating the old governmental structures" (88), and his final embrace of the zombie hordes as he walks "into the sea of the dead" (259). This has everything to do with race: that Mark Spitz, the black male protagonist of Zone One, would rather be 
swallowed up by the sea of zombies, where "[e]very race, color, and creed was represented" (243), than return to the racial inequity of "the old governmental structures." The idea of establishing institutions as bulwarks against the horrors of the outside-to "[k]eep chaos out, order in" (97), as the novel says of the old system-is deeply suspect in Zone One. The modern institution of enclosure, symbolized by the walled space of the novel's title, finally proves unequal to the task of preventing the zombie apocalypse as the undead pour into the ordered zone through a breach in the wall. Not finding anything particularly attractive about the institutions that existed before the zombies destroyed them, Spitz prefers to "[1]et the cracks between things widen until they are no longer cracks but the new places for things" (257). ${ }^{10}$

Zone One differs from The Road in that McCarthy's novel ends with the embrace of a shelter in the institution of the nuclear family, precarious as it may seem in a world of ravaging cannibals. Yet the novels are similar in respect to institutions in two important ways. First, as has already been noted, they both dramatize the outside of institutions as terrifying spaces that their characters seek shelter from. At the same time, however, they also both reject the reinstitution of a modern disciplinary order as a safe zone. If the very point of institutions for Wallace was a formal rationality devoid of substance that rescued his characters from themselves by subjecting them to mindless discipline, neither Zone One nor The Road have any illusions about this negative function of institutions as organization against the void. In fact, Judge Holden's rhetorical question to the kid in Blood Meridian-"the emptiness and the despair. It is that which we take arms against, is it not?" (329)-is eerily reminiscent of Wallace's embrace of formal institutions. The Road represents precisely such disciplinary organization in the depiction of the regimented armies that traverse the wasteland. As Robert Pirro argues, the horrifying presence of organized armies in The Road suggests "a basic skepticism about large-scale, bureaucratically organized governments." He notes that such organized groups in the novel have

institutionalized the practices of cannibalism and slavery in a way that multiplies its power and potential reach. It is worth considering to what extent the horror of the spectacle of this army inheres not only in its monstrous practices, but also in its institutionalization of a seemingly impersonal power that seems so at odds with the reciprocal, personal care which holds the father-son dyad together.

As Pirro further points out, the description of the army as "marching with a swaying gait like wind-up toys" (The Road 77) implies a mechanical quality, which since Max Weber's theory of bureaucracy has been associated with formal, instrumental rationality, in contrast to a substantive rationality based on positive values.

The form of mindless organization represented by the armies in The Road are what we might call zombie institutions: organized bodies without content. ${ }^{11}$ They are the type of modern disciplinary institution that genre was formerly conceived as: a "mold" or "box" into which content could be filled. ${ }^{12}$ The genre turn today, however, is changing our perception of genre as something far more flexible, not wholly unlike the institutional blurring of boundaries that characterizes the postmodern organization. But in contrast to the postmodern turn in organization studies, which epitomizes the anti-institutionality of the program era, The Road imagines a value base for the reconstruction of society. The reinstitution of the family in The Road is not "an institution against nothing," but based on a positive ethical distinction. As the family man in the end says: "We dont eat people" (239). To be sure, this is not much of a value judgment to build an institution on, but it nevertheless is one-and as one of the 
foundational taboos of society, it signals a new beginning. By making a substantive distinction, however basic, between the institution of the family and the cannibalistic "bloodcults" (14) in the novel, the representation of the outside of institutions is not used as a rouse to rush back into any institutional form that offers shelter, but as the spur to recreate a new value-basis for one.

To conclude, both The Road and Zone One represent the horror outside of institutions, but they also both dramatize the importance of discriminating between institutions on the basis of their encoded values. The Road in particular makes a distinction between institutions that are based on formal rules and ones that have a substantive normative basis. This is a distinction between what Douglass C. North describes as "informal constraints (sanctions, taboos, customs, traditions, and codes of conduct), and formal rules (constitutions, laws, property rights)" (97). While the transgressive, modernist aesthetic of McCarthy's early work rejects both informal and formal institutions as oppressive, his turn to genre fiction with Blood Meridian and especially the Border Trilogy-whose characters are their customs and codes of conduct-makes a distinction between these two forms of institutionality: the informal institutions of social conventions are counterpoised to the formal institutions of modernity, which uproot normative structures associated with premodern forms of social organization. This thematic shift is mirrored in the redefinition of genre itself as an informal institution of literary conventions that enables expression, rather than a view of genre as a formal institution (a "box" or "mold") that restricts expression.

The recuperation of informal conventions in The Road, however, is brought into sharp relief against the backdrop of their absence. It is significant that The Road doesn't end with the reinstitution of the family, but with the "mystery" of the nonhuman (241). The stabilizing function of the family institution is brought into dialectical tension with its outside, a tension between the institutional and extra-institutional that also structures Zone One. This dialectical tension between the inside and outside of institutions is embodied in the very form of literary genre fiction like The Road and Zone One. While genre conventions shape our expectations of a text, the challenging vocabulary, complex syntax, and estranging similes that characterize a literary style like McCarthy's or Whitehead's all challenge those expectations. The fusion of these narrative strategies creates a tension that I have read here as marking a different relationship with institutions than that described by McGurl in The Program Era. This may well indicate less the end of the program era than another reflexive turn within it -but as such it is an important one.

\section{BIBLIOGRAPHY}

Bellini, Federico. “Cormac McCarthy's The Stonemason and the Ethic of Craftsmanship." European Journal of American Studies 12.3 (2017). Web. 3 December 2017. http://ejas.revues.org/12285 
Benjamin, Walter. “The Storyteller: Reflections on the Works of Nikolai Leskov." Illuminations: Essays and Reflections. 1968. Trans. Harry Zorn. Ed. Hannah Arendt. New York: Schocken Books, 1969. 83-109. 2007. Print.

Brinkmeyer, Robert Jr. "Cormac McCarthy and the Craftsman Hero." Unsteadily Marching On: The U.S. South in Motion. Ed. Constante González Groba. Valencia: Universidad de Valencia, 2013. 59-66. Print.

Cant, John. Cormac McCarthy and the Myth of American Exceptionalism. New York: Routledge, 2008. Print.

Culler, Jonathan. “Toward a Theory of Non-Genre Literature." 1981. Theory of the Novel: A Historical Approach. Ed. Michel McKeon. Baltimore and London: John Hopkins UP, 2000. 51-56. Print.

Deleuze, Gilles. "Postscript on the Societies of Control.” October 59 (Winter 1992): 3-7. Print.

Dorson, James. Counternarrative Possibilities: Virgin Land, Homeland, and Cormac McCarthy's Westerns. Frankfurt on Main: Campus, 2016. Print.

Ellis, Jay. No Place for Home: Spatial Constraint and Character Flight in the Novels of Cormac McCarthy. New York: Routledge, 2006. Print.

Englender, Yonatan and Elana Gomel. "Post-Apocalypse Now: Cormac McCarthy's The Road as Post-Apocalyptic Science Fiction.” The Poetics of Genre in the Contemporary Novel. Ed. Tim Lanzendörfer. London: Lexington Books, 2016. 127-143. Print.

Fishelov, David. Metaphors of Genre: The Role of Analogies in Genre Theory. University Park, PA: Pennsylvania State UP, 1993. Print.

Frow, John. Genre. London and New York: Routledge, 2005. Print.

Frye, Steven. "Histories, Novels, Ideas: Cormac McCarthy and the Art of Philosophy." The Cambridge Companion to Cormac McCarthy. Ed. Steven Frye. New York: Cambridge University Press, 2013. 3-13. Print.

Genette, Gérard. “Vraisemblance and Motivation.” 1968. Trans. David Gorman. Narrative 9.3 (2001): 239-58. Print.

Grammar, John M. “A Thing Against Which Time Will Not Prevail: Pastoral and History in McCarthy's South." Eds. Edwin T. Arnold and Dianne C. Luce. Perspectives on Cormac McCarthy. Jackson: UP of Mississippi, 1993. 27-42.

Guillemin, Georg. The Pastoral Vision of Cormac McCarthy. College Station: Texas A\&M UP, 2004. Print.

Hoberek, Andrew. "Introduction: After Postmodernism." Twentieth Century Literature 53.3 (Fall, 2007): 233-247. Print.

---. “Cormac McCarthy and the Aesthetics of Exhaustion." American Literary History 23.3 (2011): 483-99. Print.

Holloway, David. The Late Modernism of Cormac McCarthy. Westport: Green-wood Press, 2002. Print. Jurgensen, John. “Hollywood's Favorite Cowboy.” The Wall Street Journal. 20 November 2009. Web. 20 October 2017. http://online.wsj.com/article/ SB10001424052748704576204574529703577274572.html

Lanzendörfer, Tim. “The Politics of Genre Fiction: Colson Whitehead's Zone One. C21 Literature: Journal of 21 $1^{\text {st }}$-century Writings 3.1 (2014): 39-52. Print. 
---. "Introduction." The Poetics of Genre in the Contemporary Novel. Ed. Tim Lanzendörfer. London: Lexington Books, 2016. 1-14. Print.

Le Guin, Ursula K. “Introduction.” 1976. The Left Hand of Darkness. New York: Ace Books, 2010. xivxix. Print.

---. The Word for World is Forrest. 1972. London: Gollancz, 2014. Print.

McCarthy, Cormac. Blood Meridian, or, The Evening Redness in the West. 1985. London: Picador, 1990. Print.

---. Cities of the Plain. New York: Knopf, 1998. Print.

---. The Road. New York: Knopf, 2006. Print.

McGurl, Mark. The Program Era: Postwar Fiction and the Rise of Creative Writing. Cambridge: Harvard UP, 2009. Print.

---. "The Institution of Nothing: David Foster Wallace in the Program." Boundary 241.3 (2014): 2754. Print.

---. “Zombie Renaissance.” n+1 Magazine 9 (Spring 2010). Web. 20 October 2017. https://

nplusonemag.com/issue-9/reviews/the-zombie-renaissance/

North, Douglass C. “Institutions.” Journal of Economic Perspectives, 5.1 (Winter 1991): 97-112. Print.

Pirro, Robert. "The Tennis Shoe Army and Leviathan: Relics and Specters of Big Government in The Road." European Journal of American Studies 12.3 (2017). Web. 3 December 2017. http:// ejas.revues.org/12359

Saldívar, Ramón. "Historical Fantasy, Speculative Realism, and Postrace Aesthetics in Contemporary American Fiction.” American Literary History 23.3 (2011): 574-599. Print.

Schmid, David. "Literary Fiction and Crime Fiction: The Case of Cormac McCarthy." The Great Courses Daily. Web. 20 October 2017.

https://www.thegreatcoursesdaily.com/the-case-of-cormac-mccarthy/

Rothman, Joshua. “A Better Way to Think About the Genre Debate.” The New Yorker. 6 November 2014. Web. 20 October 2017.

http://www.newyorker.com/books/joshua-rothman/better-way-think-genre-debate

Seltzer, Mark. The Official World. Durham and London: Duke University Press, 2016. Print.

Spicer, André. "Extitutions: The other side of institutions." ephemera 10.1 (2010): 25-39. Print.

Thompson, Lucas. "Books Are Made out of Books:" David Foster Wallace and Cormac McCarthy. The Cormac McCarthy Journal 13.1 (2015): 3-26. Print.

Whitehead, Colson. Zone One. London: Harvill Secker, 2011. Print.

\section{NOTES}

1. To be sure, the genre turn of literary fiction today is not the first time that literariness and genericity have been combined. Much genre fiction has often been noted for its literary qualities, and vice versa. What makes the combination so interesting today is the extent of the phenomena as a wholesale reorganization of the literary field.

2. See Grammar on the counterpastoral in McCarthy. 
3. See Dorson's Counternarrative Possibilities: Virgin Land, Homeland, and Cormac McCarthy's Westerns (2016) for a reading of genre in the Border Trilogy relevant to my discussion here (238-247).

4. See Brinkmeyer and Bellini on the significance of craft in McCarthy.

5. See Benjamin for the distinction between storytelling and the novel.

6. As I argue below, however, the metaphor of a "box" for genre is misleading.

7. Think of the contested Anglo-American separation of novel and romance.

8. Cf. Frow's conception of genre as “a shift away from an 'Aristotelian' model of taxonomy in which a relationship of hierarchical belonging between a class and its members predominates, to a more reflexive model in which texts are thought to use or to perform the genres by which they are shaped" (25).

9. See Thomas on Wallace's literary debt to McCarthy.

10. Cf. Lanzendörfer's reading of generic mixing in Zone One, which similarly argues that "the novel's concerns for the conflation of corporate and governmental interests, and its worry that the end of reconstruction will see little but the restitution of previous societal structures in all their unfairness, connect it to its political, nonfiction moment" ("The Politics of Genre Fiction" 44).

11. Cf. Tom McCarthy's description of zombiedom as "re-enactment without content" (qtd. in Seltzer 28).

12. Deleuze's description of the disciplinary institutional space as a "mold" in contrast to more flexible control technologies directly recalls Grillet's view of genre as a "mold": "Enclosures are molds, distinct castings, but controls are a modulation, like a selfdeforming cast that will continuously change from one moment to the other" (Deleuze 4).

\section{ABSTRACTS}

The wholesale embrace of genre fiction by contemporary literary writers is currently reorganizing the literary field. This essay looks at the role that genre has played in Cormac McCarthy's fiction since his turn to the Western with Blood Meridian (1985). It assesses his genre fiction vis-à-vis Mark McGurl's influential study of the importance of creative writing programs for postwar US fiction in The Program Era (2009). In contrast to the modernist aesthetic institutionalized in program era fiction, I argue that the recent genre turn significantly changes the relationship of literary fiction to reality as well as to institutions. I suggest that the turn to genre should be considered the formal response to a crisis in reality, triggered by twenty-firstcentury reconceptualizations of the world and our place in it, which requires new ways of representing reality. By reading McCarthy's The Road (2006) alongside Colson Whitehead's Zone One (2011), I argue that the genre turn in contemporary literary fiction also marks a turn toward institutions, one that both rejects the anti-institutionality of the program era and a return to the modern disciplinary institution in favor of rethinking a value basis for future institutions. 
INDEX

Keywords: Cormac McCarthy, genre fiction, the program era, speculative realism, institutions

\section{AUTHOR}

\section{JAMES DORSON}

James Dorson is an assistant professor at the John F. Kennedy Institute for North American Studies, Freie Universität Berlin. He is the author of Counternarrative Possibilities: Virgin Land, Homeland, and Cormac McCarthy's Westerns (2016) and the co-editor of the special issue of Studies in American Naturalism titled “Data Fiction: Naturalism, Narratives, and Numbers." He has written essays on David Foster Wallace, Edith Wharton, Frank Norris, Jack London, and business culture in the Progressive Era. His research interests include critical theory, labor fiction, business history, and literature and economics. He is currently writing a book on naturalism and the spirits of capitalism at the turn of the twentieth century. 